\author{
${ }^{1}$ R.S. Kassymova (iD , ${ }^{2}$ M.M. Suleimen \\ ${ }^{1}$ Candidate of Pedagogic Sciences, Associate Professor \\ Al-Farabi Kazakh National University, Kazakhstan, Almaty, e-mail: krs1958@mail.ru \\ ${ }^{2}$ Lecturer of the South Kazakhstan state pedagogical university, \\ Kazakhstan, Shymkent, e-mail:smm_tm@mail.ru
}

\title{
THE HISTORY AND POTENTIAL OF ART THERAPY IN THE PREVENTION OF SOCIAL PHOBIAS OF STUDENTS
}

\begin{abstract}
In the article, particularities of the preventive work of social phobias of youth are considered. According to WHO, the number of children and youth with such a diagnosis has now increased. This is an important argument in favor of the need for early detection and prevention of social phobias in order to prevent severe maladaptation, the development of persistent inadequate defense mechanisms, the occurrence of concomitant diseases such as severe depression and alcoholism. Also, the characteristic indications for prevention is the inability, due to fears, to continue to study, work, form stable social ties, etc.

The article suggests the periodization of the development of research on the prevention of social phobias. 3 stages are distinguished: Pre-Developmental Period, Initial Developmental Period, Recent Developments. It considers factors affecting the development of social phobias of youth.

A prevention program of students' social phobias was developed, as part of the research. 60 students of Al-Farabi Kazakh National University attended in the experiment. Diagnostics is made by LSAS method. The correction program included art-therapeutical methods, classes were conducted according to a program designed for 30 hours. The stabilization dynamics is shown after experimental and pedagogical work on the prevention of social phobias through art therapy methods.
\end{abstract}

Key words: social phobia, prevention, phobia, program, preventive work, art therapy, fears, social and educational methods.

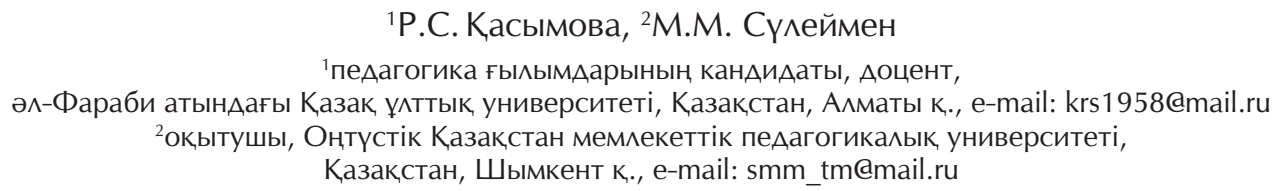

Арт-терапияны студенттердің әлеуметтік фобияларын алдын алуда қолданудың тарихы мен мүмкіндіктері

Аңдатпа. Мақаяада жастардың әлеуметтік фобияларын алдын алу жұмыстарының маңыздылығы қарастырылады. АیССҰ мәліметтеріне сүйенсек, қазір әлеуметтік фобиясы бар балалар мен жастар саны артуда. Келтірілген аргументтер салдары ауыр дезадаптация, тұрақты адекватты емес қорғау механизмдері, депрессия, маскүнемдік сияқты қосалқы аурулардың Аамуына алып келетін әлеуметтік фобияны ерте анықтау мен алдын алу қажеттілігі мен маңыздылығын көрсетеді. Сонымен қатар, қорқыныштың салдарынан оқу, жұмыс, тұрақты әлеуметтік қарым-қатынас құру және т.б. әлеуметтік қабілеттердің дұрыс қалыптаспауы алдын алу жұмыстар жүргізуге себеп болып табылады.

Мақалада әлеуметтік фобияны алдын алу жұмыстары бойынша зерттеулердің даму кезеңдері көрсетілген. 3 негізгі кезең анықталады: ғылымға дейінгі, зерттеулердің қалыптасу кезеңі (ілгері кезең), қазіргі зерттеулер. Сондай-ақ, мақалада жастардың әлеуметтік фобияларының дамуына ықпал ететін факторлар көрсетілген.

Зерттеу барысында студенттердің әлеуметтік фобиясын алдын алу бағдарламасы құрастыры^ды. Экспериметке әл-Фараби атындағы Қазақ ұлттық университетінің 60 студенті қатысты. Аиагностика LSAS әдісі арқылы жүргізілді. Түзету жұмыстарында арт-терапия әдістері қолданы^ды, сабақтар 30 сағаттық бағдарлама негізінде жүргізілді. Арт-терапия әдістері арқылы әлеуметтік фобияның а^дын алу бойынша тәжірибелі-педагогикалық жұмыстардан кейінгі тұрақтылық, динамикасы көрсетілген.

Түйін сөздер: әлеуметтік фобия, профилактика, фобия, бағдарлама, алдын алу жұмыстары, арт-терапия, қорқыныштар, әлеуметтік-педагогикалық, әдістер. 


\author{
1P.С. Касымова, ${ }^{2}$ М.М. Сулеймен \\ ${ }^{1}$ кандидат педагогических наук, доцент, Казахский национальный университет им. а^ь-Фараби, \\ Казахстан, г. Алматы, e-mail: krs1958@mail.ru \\ ²преподаватель, Южно-Казахстанский педагогический университет, \\ Казахстан, г. Шымкент, e-mail: smm_tm@mail.ru
}

История и потенциал арт-терапии в профилактике социальных фобий студентов

\begin{abstract}
Аннотация. В статье рассматриваются особенности профилактической работы по социальным фобияммолодежи. По Аанным ВОЗ, в настоящее время увеличилось количество Аетей и молодежи с таким диагнозом. Это является важным аргументом в пользу необходимости раннего выявления и профилактики социальных фобий с целью предотвращения тяжелой дезадаптации, развития устойчивых неадекватных защитных механизмов, возникновения сопутствующих заболеваний, таких как тяжелая депрессия и алкоголизм. Также, характерным показанием Аля профилактики является неспособность из-за страхов продолжать учиться, работать, формировать устойчивые социальные связи и т. А. В данном процессе необходима и важна работа социального педагога.

В статье предложена периодизация развития исследований по профилактике социальных фобий. Выделены 3 этапа - донаучный, зарождения исследований (начальный период), современных исследований. В статье рассмотрены факторы, влияющие на развитие социальных фобий молодежи.

В рамках исследования была разработана программа профилактики у студентов социальных фобий. В эксперименте участвова^и 60 студентов Казахского национального университета им.аль-Фараби. Аиагностика проводилась методом LSAS. Программа коррекции вк^ючала арт-терапевтические методы, занятия проводились по программе, рассчитанной на 30 часов. Показана положительная динамика после опытно-педагогической работы профилактики социальных фобий методами арт-терапии.
\end{abstract}

Кмючевые слова: социальная фобия, профилактика, фобия, программа, профилактическая работа, арт-терапия, страхи, социально-педагогические методы.

\section{Introduction}

Issues of maintaining and developing the psychological health of youth through the education system are being actively raised in Kazakhstan.

Mental health is an integral part and an essential component of health. According to the conclusion of the World Health Organization "Health is a state of complete physical, mental and social well-being and not merely the absence of disease or infirmity" [1]. An important consequence of this definition is that mental health is not only the absence of mental disorders and forms of disability, this state of wellbeing in which a person realizes his abilities, can resist ordinary life stresses, work productively and contribute to his community.

Mental health has essential meaning for our collective and individual ability as an intelligent beings to think, express emotions, communicate with each other, earn their living and enjoy life. Given this fact, strengthening, protecting and restoring mental health can be perceived by individuals, communities and common wealth around the world as actions of vital importance.

Social phobia (after SP) is the third largest problem of mental health in the world after alcoholism and depression. According to the SAA and the latest government epidemiological data, about $7 \%$ of the population suffers from any form of social anxiety disorder [2].

Social phobia is a fear of social situations. It is characterized by a pronounced fear or anxiety of one or more social situations in which a person is subjected to possible control by others. For example, social interactions (conversation, meeting with strangers), observed by someone (eating or drinking) and performing in front of others. Mass social phobia is the result of the functioning of modern society; on the other hand, social phobias arise in the process of adaptation to environmental changes, mobilize opposition and overcome dangers and threats to the existence of individuals and groups.

Researchers note that at different periods of life SP affects every tenth person. About $40 \%$ of cases of SP begin before 10 years of age, and $95 \%$ - up to 20 years. Students experience the first manifestations of SP particularly hard. Because the education is sometimes the real clash with the model of "society of strangers". SP is not recognized during childhood, because it is often associated with shyness and behavioral inhibition and in adult life SP leads to a number of secondary comorbid conditions. The most serious of secondary comorbid conditions are alcoholism and the medicines and drugs abuse. Also, 
it can follow a chronic, unremitting course and lead to substantial impairments in vocational and social functioning, if the problem is left untreated.

The purpose of the article - periodization of the history of the development of social phobias studies, surveys of social phobias of students - future social teachers in modern professional training content and to show potential of art therapy in the prevention of social phobias of students.

\section{Research methods}

The development of research on the prevention of social phobias was briefly analyzed, methods of periodization were used, scientific sources were compared, experimental and pedagogical work on the diagnosis and correction of social phobias through art therapy methods is conducted in the article. The LSAS method was used in diagnostics.

For a long time fear as an emotional state of a person excited the consciousness of not only ordinary people, reflected in folk tales and legends, but also served as an object of consideration for philosophers.

Then, in the first half of the 20th century, psychologists joined the study of the problem of fear and anxiety like philosophers.

Fear was studied as a factor determining the development of modern society (W. Beck, A. Wildawski, E. Giddens, C. Dyke, M. Douglas, S.A. Kravchenko, S.A. Krasikova, N. Luman, F. Knight, N.L. Smakotina, K.A. Feofanova and others). Mass social fears are treated as an assessment of the state of the environment, a characteristic of social security. Social fears are also the subject of consideration of the sociology of security (K.K. Isayev, V.N. Kuznetsov, V.K. Levashov, R.G. Yanovskiy). The basic principles of the study of social well-being and social mood are reflected in the works of E.I. Heads, H.L. Panina, L.E. Keselman, M.G., Matskevich, J.N. Krupets, K. Muzdybaeva, L.E. Petrova, J.T. Toshchenko, S. Kharchenko and others. Analysis of socio-cultural determinants of the emergence and development of social fears is presented in the works of A. Akhisera, T.I. Zaslavskaya, K. Kasyanova, S. Kara-Murza.

Today, interest in fear and anxiety is the same, philosophers, sociologists, political scientists, psychologists, psychiatrists, physiologists, educators continue to study the different sides of this emotional phenomenon. Philosophers see in it a kind of existential force that determines the evolution of the human soul; sociologists and political scientists see fear as a means of manipulating the human masses; psychologists pay attention to the protective function of fear, which contributes to the survival of the individual in extreme conditions, develop practical methods for overcoming fear and anxiety.

The brief history and overview of social phobia In the literal translation, the word "social phobia" means "fear of society".

The recognition of social phobia happened slowly and was based on the studies in the field.

There are 3 main stages of the historical developments of studies on social phobia: Pre-Developmental Period, Initial Developmental Period, Recent Developments.

Pre-Developmental Period consists of the early years when social anxieties and fears were described as shyness and began to be systematically delineated with other phobias in the 1870 s.

The term "phobia" was coined by the Greeks and connected with a name of the fear god - Phobos.

In early 400 B.C. social anxiety was first described as "shyness" by Hippocrates, he marked shy people as who "love darkness as life" and "think every man observes him".

During the XVIII century, psychiatrists, psychologists, and authors started examining many manifestations of social anxiety were raised. They used it to refer to extremely shy patients.

In the Initial Developmental Period (since the middle of the XIX century) it has own description with these that are now designated as social phobia, which are operationalized as fear of public speaking, triggering anxiety about the moral situation in the circle of people.

As psychic phenomena, SP are mentioned from the very beginning of psychiatric practice (H. Duboux, G.O. Casper, P. Janet, P. Hartenberg, E. Kraepelin, V.M. Behterev, F.E. Rybakov, V.F. Shyzh, V.I. Yikovenko, D.V. Yastrebov) (Liebowitz M.R. 1992), (Yastrebov D.V. 2000) [3], [4].

But only in 1903 the term "social phobia" was first introduced by P. Janet to describe patients who feared being observed, for example while speaking or writing (P. Janet, 1903) [5].

However, both in domestic and in foreign clinical psychology and psychiatry, this disease has long been considered either as a symptom of other, more severe psychiatric disorders, or as a separate syndromic manifestation.

The British psychiatrist Isaac Marks observed in the 1960s that particular phobias, including social phobia, could be distinguished from each other by age of onset. As recently as 1985, a research group of Liebowitz, Gorman, Fyer, and Klein described social phobia as "a neglected disorder" (Fyer, A. J., Liebowitz, M. R., Klein, 1993) [6]. 
In 1980 in the third edition of the DSM that social phobia got its own specific diagnosis. In our country only since the late 80 's.of XX century SP begins to act as a separate nosological unit (American Psychiatric Association 1980) [7].

Currently, on Recent Developments SP describes as mental disorder. It has the status of an independent mental disorder within the ICD-10, criteria for psychiatric diagnosis, medical and psychotherapeutic treatment have been developed. In the clinical review of WAP, individuals with SP are described as follows: "persons with SP are experiencing an inadequate fear of negative evaluation by others in a number of situations of social interaction. In a situation that causes fear, they often have anxiety, and its somatic manifestations are noted. Some people suffering from social phobia do not make any physical complaints, but they feel very awkward, afraid and apprehensive" [8].

There is an integrated model developed by the research group of R.G. Heimberg for presenting the general picture of social phobias:

1. Genetic and environmental factors (genetic influences, parents' anxiety, parents' attitudes towards the upbringing of children, negative experience with the reference group and/or representatives of the opposite sex);

2. Beliefs about social situations (social situations are potentially dangerous, in order to avoid danger in social situations, behavior must be perfect, I do not have the abilities necessary to behave properly);

3. Forecasts about social situations (social situations inevitably lead to trouble, denial, humiliation, loss of status);

4. Symptoms of anxiety (anxious expectation of social situations, concentration of attention and focus on socially threatening irritants, negative thoughts about oneself, about one's behavior and evaluation of oneself by others, increased physiological arousal, strong concern about the obviousness of anxiety symptoms);

5. Consequences of anxiety (real or imagined behavioral disorders, perception of one's own behavior and its evaluation according to the criteria of perfectionism, evaluation of one's own behavior as inadequate, focusing on imaginary negative consequences of inadequate behavior) [9].

Common types of fears associated with social phobia are: fear in performance situations (public speaking; eating or drinking in front of others; writing in front of others; speaking in a group; entering a room where others are seated; using public toilets) and fear in interaction situtions (interacting with others; conversing on the telephone; speaking with strangers; dating; interacting with the opposite sex; attending social gatherings; dealing with authoring figures)

Social phobias can include the fear of many young guys to get acquainted with the girl they liked, also, the fear of "losing" a loved one. At the heart of this fear, as a rule, lies deep self-doubt and low self-esteem, as well as negative experience in this area.

There are four major approaches to describe causes of social phobia. They are: The skills deficit model which assumes that anxiety experienced in social situations is due to an inadequate or inappropriate repertoire of social skills. The second one is cognitive self-evaluation model. It states that social anxiety results not from an objective skills deficit per se but from the individual's perception of personal inadequacies. The classical conditioning mod$\mathrm{el}$, assumes that social anxiety is conditioned when neutral stimuli become paired with aversive social consequences and the fourth approaches, a personality trait, investigating individual differences in the affective, cognitive, and behavioral concomitants of social anxiety [10].

William James recognized that social situations can elicit different self-features. He noticed that (A man) has as many different social selves as there are distinct groups of persons about whose opinion he cares. He generally shows a different side of himself to each of these different groups (James, 1890) The notion that the self contains internalized representations of significant others is also reflected in contemporary theories of social anxiety.

The below table considers the theories, each of which describes the role of the self in social anxiety. (see Table 1) [11].

SP typically begins early in life and follows a chronic course, often resulting in comorbid presentations at some time in the lives of people who suffer from it. In many cases, comorbidity is associated with greater functional impairment and lower quality of life.

Although anxiety is accepted as part of the learning process, there is little thought given to the impact of social anxiety. Yet social anxiety in learning situations such as seminars and presentations can inhibit student participation and impair the quality of student life.

Studies have reported significant effects of social anxiety on failure to complete school, increased risk of exam failure, failure to graduate and reduced income. 
Table 1 - Social anxiety teories

\begin{tabular}{|c|l|c|}
\hline $\begin{array}{c}\text { Social anxiety } \\
\text { teories }\end{array}$ & & \multicolumn{1}{|c|}{ Description } \\
\hline The Strategic Self & $\begin{array}{l}\text { Social anxiety arises when people are motivated to make a certain impression on } \\
\text { others but doubt their ability to do }\end{array}$ & Leary, M. R. \\
\hline The Discrepant Self & $\begin{array}{l}\text { Social anxiety arises when the person becomes aware of a discrepancy between } \\
\text { the actual and ought-other self-representations. }\end{array}$ & $\begin{array}{c}\text { Strauman, T. J., \& } \\
\text { Higgins, E. T }\end{array}$ \\
\hline The Relational Self & $\begin{array}{l}\text { Social anxiety as reason of negative social expectancies arise as the result of } \\
\text { the activation of relational schemas involving social evaluation and disapproval. }\end{array}$ & Baldwin, M. W \\
\hline The vulnerable self & $\begin{array}{l}\text { The anxiety disorders are hypothesized to stem from the activation of the } \\
\text { vulnerability mode, which prepares the organism to cope with danger and } \\
\text { enhances safety }\end{array}$ & Beck, A. T. \\
\hline The distorted self & $\begin{array}{l}\text { SP is based on the of biased information processing, which activate an "anxiety } \\
\text { program" designed to protect the person from harm. }\end{array}$ & Clark, D. M., \& Wells, A. \\
\hline The Threatened self & People with SP place a high value on being positively appraised by others & $\begin{array}{c}\text { Rapee, R. M., } \\
\text { \&Heimberg, R. G. }\end{array}$ \\
\hline
\end{tabular}

When participating in a seminar or presentation, socially anxious students judge their competence poorly, in contrast to the more positive evaluations of observers, the threat of negative social evaluation persists regardless of academic achievement. In undergraduate programmes, academic material becomes progressively more challenging, and anxieties rise where assessment includes performance or presentation. Socially anxious students miss out on learning opportunities by avoiding interaction, physically or psychologically. Attention to academic information may be distracted by an excessive focus on their anxieties, while the ability to monitor and modify communication with colleagues and tutors may be distorted by fears of negative evaluation.

If untreated, only one third of individuals attain remission from social anxiety within 10 years, suggesting that identification and early intervention will be beneficial to individuals, families and the public purse.

Social phobia often coexists with other mental health issues. According to the WAP, social phobia is "the primary pathology in $70.9 \%$ of people with comorbid depression, $76.7 \%$ with comorbid addiction and $85 \%$ with comorbid alcoholism". These indicators are another argument in favor of the need for early detection and treatment of SP with the aim of preventing the development of the most common pathologies: "Among them, simple phobias predominate $-59 \%$, agoraphobia (fear of open spaces) - $44.9 \%$ alcoholism - $17 \%$, drug abuse $17 \%$. It is also noted that there is a close relationship between SP and the subsequent development of a nutritional disorder, such as obesity" [12].

An increasing number of SP diseases reveals the lack of meaningful and formal ways of psychoprophylaxis, psychotherapy and rehabilitation of those suffering from this disease.The early onset of therapy can prevent severe maladaptation, the development of resistant inadequate protective mechanisms (semantic defects) the emergence of comorbid conditions such as severe depression and alcoholism. However severe the violations related to SP may be, they can be prevented or weakened. Early prevention is the key to success. Indisputable indications for prevention are pronounced psychosocial disorders: the inability, due to fears, to continue learning, working, forming stable social ties, etc.

\section{Prevention of social phobia}

Prevention is a system of economic, social, hygienic and medical measures. It is carried out by the state, public organizations, individual citizens in order to ensure a high level of public health and prevent diseases.

There are several reasons why further evaluation and development of prevention of anxiety and phobia is needed. First, only a few students with social anxiety use phsychological-pedagogical service at university. Second, the most people don't know what is social phobia and anxiety. Finally, although there is evidence of effective treatments for anxiety and depression in youth, treatment dropout is not uncommon, and some researchers argue for 
the benefit of early prevention before negative cognitive and behavioral patterns have been solidly established.

The success of prevention programs for social phobia of youth depends a great deal on having early detection and screening strategies in place at key access points where youths might be identified.

All programs of prevention are originally an adaption of a cognitive-behavioral treatment. Behavioral therapy has a wide range of different therapeutic methods. To the technicians demanding to represent a problem situation in imagination, the systematic desensitization concerns.

For example, a program of special interest is the widely evaluated Australian program FFL (Friends for life) developed by P. Barrett. The FRIENDS programs are acknowledged by the World Health Organisation as effective evidence based prevention programs [13].

The word "friends" is an acronym, meaning that each letter (F-R-I-E-N-DS) represents a skill (or concept) learned in the program. The skills are supposed to build on each other, which is why the program is recommended to be implemented according to the structure of the FFL-manual.

Also, Melfsen and colleagues have developed and evaluated a small-group cognitive-behavioral training program. This program for children of ages 9-12 and includes cognitive interventions, exposure exercises, and training in social skills [14].

Tuschen-Caffier et al. developed a cognitivebehavioral program for children between the ages of 8 and 14, which includes three intervention modules linking the diagnostic phase and the cognitive preparation for therapy (cognitive interventions, behavior-building interventions, exposure exercises) and completed by a module for prevention of relapse and for self-management [15].

Ahrens-Eipper and Leplow have developed a cognitive-behavioral training program ("Mutig werden mit Til Tiger", or "Be Brave with Til the Tiger"). This program consists 2 individual sessions and 9 group sessions, where children aged 5-10 who suffer from social insecurity learn to systematically observe their own behavior and to try out alternative behavior [16].

We created the $\mathrm{CtC}$ program that is similar with it. The main specific of this program that only art-therapy's techniques were used during the prevention work.

Also, many authors believe that it is the methods of art therapy that compensate for some of the shortcomings in the cognitive approach associated with the need for a high level of awareness, reflection, self-monitoring, in particular drawing techniques, help express their fear to children, as well as people in a difficult psychological state, it is difficult going to contact or pushing out experiences.

Art therapy in the prevention of social phobias can perform diagnostic, communicative, regulatory, cognitive, corrective, developmental functions.

There are two reasons why art-therapy could be effective in helping to prevent social phobias. First, it has developing function to create social and emotional competencies (self-awareness, socialawareness, self-management and self-regulation) and, the second reason is diagnostic function that giving posibilies to find the students at risk-group easily and the reason of fear on unconscious level.

As art-technologies can be used not only for therapeutic and corrective purposes, but also for developing, training and preventive works, hence art-techniques can be adapted and built into the context of personal development in educational area.

In our opinion, Art technologies provide an opportunity to authenticly observe the results of their actions and their influence on others, to master new roles and to allow latent qualities of the individual, and also to observe how the modification of role behavior affects the relationships with others. All this increases the self-esteem of the individual, leads to the strengthening of personal identity, develops decision-making skills and greater freedom in situations of interpersonal and group communication.

The types of early detection of social anxiety strategies are important in work of social educator in the supporting of students in their socialization and adaptation in new place and in building healthy communication with group and pedagoges.

To find out the effectiveness of the applied art therapy, we had to determine the level of social anxiety. We use LSAS for social phobia of adults is universal scale created by M. Lieboweitz for it. This technique is used to assess the human response in various social situations and to clarify the presence or absence of social phobias. It consists of 24 sitations, where you need to choose two suitable answers, from the section "Fear" and "Avoidance".

\section{Research results and discussion}

Our study was held on the basis of the alFarabi Kazakh National University. The study was involved by 60 full-time students of speciality Social education and self-cognition.

At the first stage of the study, we divide all the students into 4 groups: students who have not expressed social phobia, students who have moderate 
social phobia, students who have expressed social phobia, and students who have strong form of social phobia.

Working on the study, we found that $13.3 \%$ of students have not expressed social phobia, $40 \%$ students have moderate social phobia, $20 \%$ students have expressed social phobia, and $26.7 \%$ students have strong form of social phobia.

The test of LSAS also allows us to build a hierarchical model of the most "terrible" and "avoided" social situations for young people.

According to the results of our research, the most "Terrible" social situations: acting, performing or giving a talk in front of audience, talking to people in authority, trying to pick up someone.

The main "Avoided" social situations: trying to pick up someone, working while being observed, acting, performing or giving a talk in front of audience.

So, we compared the above data, and results are - students are most fear of performing actions on the public and avoid public actions.

Student life presents a constant encounter with social situations of success assessment, many of which are unpleasant emotionally, predicting the unsuccessful outcome of the situation by students provokes them the emergence of a whole complex of negative experiences, transforming either into their avoidance or somatization, depression, other forms of heterogeneous mental pathology. Social fears in educational situations are the most typical for students, but it was noticed that for teachers, performances in front of the audience (especially at the beginning of the professional path) are quite uncomfortable activities. In educational life it is advisable to talk about social fears in the system "student - teacher". The consequences of expressed social fears can be a deterioration in the health of the student (due to comorbid dependencies, depression), a decrease in his academic performance, isolation from educational activities and even suicidal behavior.

To correct the social phobias of students we have conducted 30 hours art lessons. The training workshop which consisted mainly of the latest techniques and directions of art therapy aimed at the diagnosis and correction of social phobias and the development of social skills of youth.

All exercise of art-lessons 3 way direction:

exercises directed to control physical symptoms of anxiety: relaxation and breating exercises; dance and music therapy.

exercises directed to self-knowledge: all technologies of art-therapy, mandala therapy, drawing technologies, fractals drawing, zentangl, etc.

exercises directed to improve social skills: therapy uses acting, observing, dramatization, view point techniques, etc.

Prevention work at universities may include the following topics: Me and my fear; I am as a person; "Me and others" communication training; Who I am for others and for myself; Friendship and love; Life as a game; The opinions of others: how to take; All life as an exam; Fear of failure; The psychology of the masses: How to be perfect; Ideal I am and etc.

At the control stage to identify the dynamics of changes in the level of social phobias of students. The results of repeated diagnostics showed the following (see Fig. 1).

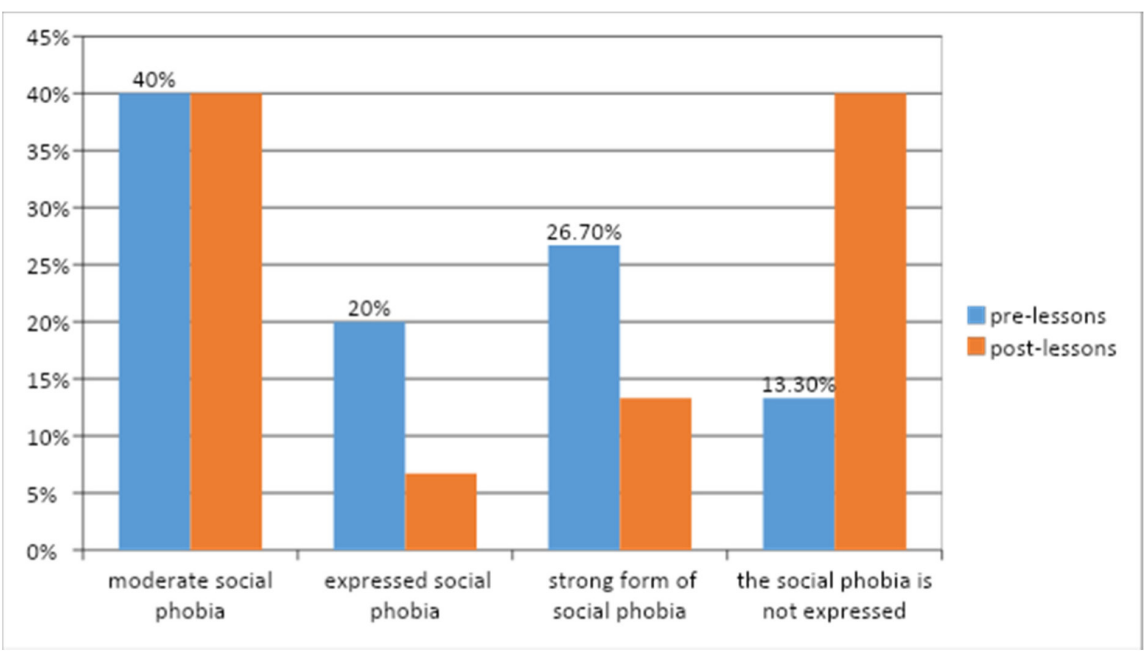

Figure 1 - The level of social phobias of "art-group" 
Comparative chart shows (see Fig. 1) that level of:

- students who had a expressed SP decreased from $20 \%$ to $13.3 \%$;

- students who had $26.70 \%$ strong form of SP decreased to $13.3 \%$.

- An moderate SP and not expressed SP have the same percentage although they had an ESP 40 $\%$ and not expressed $13.30 \%$. It's mean that level of students who don't have increased by $26,7 \%$.

A comparison of the results of the repeated diagnosis of the level of social phobia of youth showed that it is possible to reduce the level of social phobia of students by means of art therapy, and also to improve psychological well-being in general.

We asked also to use one exercise of art-therapy before they are going to have exam to check the reliability of our study. After we tested the level of anxiety of all students, not only art-group and checked their results.

So, the level of art-group students showed that they feel more comfortable during the exam than other students. Also, the results of their work became better than they were.

This shows that in all groups, the percentage of respondents who are tormented by their fears interfere with living a full life is very high.

We report that some students could not participate in this research till the end. All 3 dropouts said that their reason were that they felt anxiety before exams and refused to participate at that particular measurement. But others continued to follow our instructions. They said that art-therapy helped to control their feelings and directed their thinks to answer the exam questions.

We believe there are at least three reasons why students continued use art techniques before having exam: (a) Participants liked the process of using arttechniques (b) Art-techniques helped to constructed thinks and feelings and relax (c) participants were occasionally reminded that the results of this research are important and would likely benefit many individuals.

Prevention of social anxiety and phobias by the means of art therapy that students encounter during their studies, in their daily lives is due to its fundamental multifunctionality.

According to our research results, we can show several advantages of the using art-therapy to overcome social phobias.

Art-therapy:

allows to address those real problems or fantasies that for some reason are difficult to discuss;

allows to circumvent the "censorship of consciousness", therefore, provides a unique opportunity to study unconscious processes, express and actualize hidden ideas and conditions, those social roles and behaviors that are in the "crowded out" form, or weakly manifested in everyday life;

enables on a symbolic level to experiment with a variety of senses, explore, and express them in a socially acceptable manner. The work on the drawings, pictures, sculptures - a safe way to discharge the destructive and self-destructive tendencies;

involves an atmosphere of trust, high tolerance and attention to the inner world of man;

makes people positive emotions, it helps overcome apathy and lack of initiative, to develop a more proactive stance;

it based on the healthy potential of the individual, internal mechanisms of self-regulation and healing develops a sense of internal control.

increases the adaptive capacity of the student to the daily life and the social environment.

reduces fatigue, negative emotional states and their manifestations associated with learning.

Despite of all the advantages of art therapy in working with students, there can be some problems such as:

in work with an adult audience, some art therapy techniques may seem slow, intrusive;

not all techniques can be carried out in classrooms, which requires the creation of a special room for free work with students, but also to create a favorable space;

some adults may resist working with art therapy, citing a lack of creativity, skill, and imagination. and students with social phobia may even refuse because afraid to show the result of their work.

Therefore it is very important to create a confidential atmosphere on the first day of work.

\section{Conclusion}

The success of the development and socialization of the individual depends on many factors, including the system of relations with adults, peers in an educational institution and family. At the same time, an important place in the social environment is given to leisure and cultural and leisure activities, as the medium of leisure communication is considered as a field for the spiritual formation of the personality, its activity, initiative, independence, creative manifestations.

Based on the analysis of modern research, it is necessary to note the psychological, pedagogical and socio-pedagogical prerequisites for the use of art technologies in the process of preparing students and correcting social fears. 
So, the prevention of anxiety disorders andother mental health problems by implementing universal intervention involving phsychologist and social educators already in placein the community setting may improve socialization and adaptation proces of youth at university and society. By involving and training social educators intensively in the skillsand techniques surrounding the prevention of anxiety through make positive atmosphere at class and correction social anxiety by using art-therapy techniqes, and get significant advances in our knowledge of how best to design and implement preventive programs for young people with anxiety disorders and other mental health problems will be made.

\section{References}

1 World Health Organization. (2014) Basic documents. 48th edition. WHO press. World Health Organization, 20. Geneva, $214 \mathrm{p}$.

2 Kessler R.C., Chiu W.T., Demler O., Walters E.E. (2005) Prevalence, severity, and comorbidity of twelve-month DSM-IV disorders in the National Comorbidity Survey Replication (NCS-R). Archives of General Psychiatry, Vol. 62(6), pp. 617-627.

3 Krutko I.S., Suleimen M.M. (2018) Social phobias of youth. Science and life of Kazakhstan. Vol 4 (61), pp. 184-187

4 Liebowitz M.R. Schneier F.R., Hollander E. et al. (1992) Treatment of social phobia with drugs other than benzodiazepines. Journal of Clinical Psychiatry. Vol. 52 (suppl Nov), pp. 10-15.

5 Yastrebov D.V. (2005) Sotsial'naya phobia I sensitivnyie idei otnosheniya (klinika I terapiya) [social phobia and sensitive ideas of relationship (clinic and therapy)]: Avtoref. diss. ... cand. med.nauk: 14.00.18. M. 26 s. (In Russian)

6 Pitman, R.K. Psych Quart (1984) Janet's Obsessions and Psychasthenia: A synopsis. Kluwer Academic Publishers-Human Sciences Press. Vol. 56, Issue 4, pp. 291-314

7 Fyer, A. J. Mannuzza S., Chapman T.F., Liebowitz M.R. \& Klein D.F. (1993) A direct-interview family study of social phobia. Archives of General Psychiatry. Vol. 50, pp. 286-293.

8 American Psychiatric Association. (2013) Diagnostic and statistical manual of mental disorders (5th ed.) Arlington, VA, American Psychiatric Association.

9 World Health Organization (1992). The ICD-10 classification of mental and behavioural disorders: Clinical descriptions and diagnostic guidelines. Geneva, World Health Organisation.

10 Heimberg, R. G. Ledley, D. R. (2006) Cognitive vulnerability to social anxiety. Journal of Social and Clinical Psychology, Vol. 25, pp.755-778.

11 Barry R. Mark R. Leary (1982) Social Anxiety and Self-Presentation: A Conceptualization and Model. Psychological Bulletin. Vol. 92, No. 3, pp. 641-669

12 Weiner, B. (2005) Social Motivation, Justice and the Moral Emotions: An Attributional Approach. London: Lawrence Erlbaum Associates. $221 \mathrm{p}$

13 Anthony Seldon. (2007) Blair's Britain 1997-2007. Cambridge: Cambridge University Press. 690 p.

14 Briesch A.M., Sanetti L.M., Briesch J.M. (2010) Reducing the prevalence of anxiety in children and adolescents: An evaluation of the evidence base for the FRIENDS for Life program. School Mental Health, Vol. 2, pp.155-165.

15 Melfsen S., Osterlow J., Beyer J., Florin I. (2003) Evaluation eines kognitiv-behavioralen Trainings für sozial ängstliche Kinder. Z. Klin Psychol Psych. Vol. 32, pp. 191-199

16 Tuschen-Caffier B, Asbrand J., Schmitz J., Krämer M., Nitschke K., Heinrichs N. (2019) Effects of Group-Based CBT on Post-Event Processing in Children with Social Anxiety Disorder Following an Experimental Social Stressor. Springer US. Vol. 47, Issue 12, pp. 1945-1956

17 Kühl S., Bender C., Kley H., Krämer M., Tuschen-Caffier B. (2010) Prevention of Social Anxiety Disorder in Children and Adolescents: Necessary or Needless? (English Version). Verhaltenstherapie. Vol.20, pp. 239-246

18 Onalbekov E.S., Suleimen M.M. (2018) Art technology of prevention of social phobias of youth. Science and life of Kazakhstan. Vol 4 (61) pp. 161-165

19 Liebowitz (2014) Test for Social Anxiety Disorder. Columbia University Medical Center, New York.

\section{References}

1 World Health Organization. WHO remains firmly committed to the principles set out in the preamble to the Constitution// [online]. Available from URL: http://www.who.int/about/mission/en/ [free access]

2 Social Anxiety Association. The material from the Social Anxiety Association site // [online]. Available from URL: http:// socialphobia.org/[free access]

3 Liebowitz M.R. Treatment of social phobia with drugs other than benzodiazepines/

4 Liebowitz M.R., Schneier F.R., Hollander E. et al. // Journal of Clinical Psychiatry. - 1992. - Vol. 52 (suppl Nov). P 10-15.

5 Ястребов Д.В. Социальная фобия и сенситивные идеи отношения (клиника и терапия): Автореф. дис. ... канд. мед. наук. - М., 2000

6 Janet P. Les obsessions et la psychasthenie./Janet P. // Paris. Alcan. - 1903. -Vol. I.- 782 p.: Vol. II. 543 p. 
7 Fyer, A. J. A direct-interview family study of social phobia./ Fyer, A. J., Mannuzza, S., Chapman, T. F., Liebowitz, M. R., \& Klein, D. F.//Archives of General Psychiatry, 1993- Vol. 50, -P. 286-293.

8 American Psychiatric Association: Diagnostic and statistical manual of mental disorders (3rd ed.) (DSM-III). - Washington, DC: Author.- 1980

9 World Health Organization (WHO): The ICD-10 classification of mental and behavioural disorders: Clinical descriptions and diagnostic guidelines. Geneva, World Health Organisation, 1992.

10 Heimberg, R. G. Cognitive vulnerability to social anxiety/Ledley, D. R., Heimberg, R. G. //Journal of Social and Clinical Psychology, - 2006 - Vol. 25, P.755-778.

11 Barry R. Social Anxiety and Self-Presentation: A Conceptualization and Model./Barry R., Mark R. Leary// Psychological Bulletin - 1982 - Vol. 92, No. 3, P. 641-669

12 Weiner, B. Social Motivation, Justice, And The Moral Emotions: An Attributional Approach./ Weiner, B. - London: Lawrence Erlbaum Associates. - 2005 - P. 221.

13 Anthony Seldon. Blair's Britain 1997-2007/ Anthony Seldon. - Cambridge: Cambridge University Press.- 2007 - P. 690.

14 Briesch, A.M. Reducing the prevalence of anxiety in children and adolescents: An evaluation of the evidence base for the FRIENDS for Life program/ Briesch, A. M., Sanetti, L. M. H., Briesch, J. M.//School Mental Health, Vol. 2, - 2010 - P.155-165.

15 Melfsen S: Evaluation eines kognitiv-behavioralen Trainings für sozial ängstliche/ Melfsen S, Osterlow J, Beyer J, Florin I// Kinder. Z Klin Psychol Psych - 2003; - 32: P. 191-199.

16 Tuschen-Caffier B, Krämer M, Seefeld W, Heinrichs N: Evaluation of a cognitive-behavioral group treatment for childhood social anxiety disorder in a randomized clinical sample. Presentation at the 6th World Congress of Behavioral and Cognitive Therapies. Boston, 2010.

17 Kühl S., Bender C., Kley H., Krämer M., Tuschen-Caffier B. (2010) Prevention of Social Anxiety Disorder in Children and Adolescents: Necessary or Needless? (English Version). Verhaltenstherapie. Vol.20, pp. 239-246

18 Onalbekov E.S., Suleimen M.M. (2018) Art technology of prevention of social phobias of youth. Science and life of Kazakhstan. Vol 4 (61) pp. 161-165

19 Liebowitz (2014) Test for Social Anxiety Disorder. Columbia University Medical Center, New York. 